\title{
Biostratigraphy and assemblage composition of benthic foraminifera from the Manihiki Plateau, southwestern tropical Pacific
}

\author{
JOACHIM SCHÖNFELD \\ GEOMAR Research Center for Marine Geosciences, Wischhofstrasse 1-3, D-24148 Kiel, Germany
}

\begin{abstract}
Pleistocene and late Pliocene benthic foraminifera from the Manihiki Plateau (southwestern tropical Pacific) were studied at piston-core $34 \mathrm{KL}$. A new benthic foraminiferal biozonation is proposed. It comprises the Nodogenerina sagriensis Partial Range Zone from core base to $566.5 \mathrm{~cm}$ and the Fissurina seminiformis Partial Range Zone from this level to core top. The boundary is defined by the last occurence of Nodogenerina sagriensis which is time equivalent to the 'Stilostomella extinction' in the Eastern Atlantic. High abundances of Cibicidoides wuellerstorfi indicate a strong influence of near-bottom currents. The absence of high-productivity sensitive species reveals a low flux of organic matter to the sea floor from which a considerable amount is adduced by lateral advection. J. Micropalaeontol. 14(2): 165-175, October 1995.
\end{abstract}

\section{INTRODUCTION}

As with other fossil groups, benthic foraminifers are widely used for biostratigraphical subdivisions. Their early evolution resulted in a high degree of environmental adaption among species which is often recognized as facies dependancy. Accordingly, biostratigraphical correlations by using benthic foraminifers are often difficult in the late Cenozoic. Deep-sea benthic foraminifers display in addition considerable extended stratigraphic ranges as many of them appeared first in the early Cenozoic.

A first subdivision of the Neogene and Quaternary by using benthic foraminifers was attempted by Lutze (1979; fig. 7) who discerned five faunal units, NB5a to NB6c at DSDP Site 397 (Northwest-African continental margin). The extinction of five Pliocene species and genera marks the major faunal change in this section, i.e. the NB5/6 boundary, which roughly correlates with the boundary of Brunhes/Matuyama magnetochrons. This Stilostomella extinction event was confirmed from other locations in the eastern Atlantic by Caralp (1984) and compiled by Weinholz \& Lutze (1989) who described an irregular extinction pattern of Stilostomella and associated taxa over a time interval of more than 160000 years around the Brunhes/Matuyama boundary. The Stilostomella extinction was not recognized, however, by Berggren \& Miller (1989) for their Cenozoic bathyal and abyssal foraminiferal zonation.

A benthic foraminiferal biozonation has not been proposed to date for Quaternary deposits from the Pacific. Data suggest that the 'Stilostomella extinction' may also occur in this realm (Gupta, 1993; Resig, 1976, tab. 1; Keller, 1980, tab. 2,3; Schönfeld \& Spiegler, in press). However, the last occurrence data of Stilostomella and affiliate taxa have not been determined precisely in relation to other biostratigraphic data, oxygen isotope events, or magnetostratigraphic datum levels.

On R.V. Sonne-cruise SO67 in 1990, piston core 34KL was taken from the high-plateau area of the Manihiki
Plateau, about $148 \mathrm{~km}$ southwest of Manihiki Island (Cook Islands) at $11^{\circ} 0.1^{\prime} \mathrm{S}, 162^{\circ} 15.8^{\prime} \mathrm{W}$, and $2612 \mathrm{~m}$ waterdepth (Fig. 1; Beiersdorf, 1990). The piston core recovered $1620 \mathrm{~cm}$ foraminiferal-nannofossil ooze of light yellowish brown to white color (Fig. 2). The sediment is homogenously bioturbated; a few distinct burrows, mainly Zoophycos, are visible.

As the site is well above the calcite compensation depth and far away from continental sources, core $34 \mathrm{KL}$ was chosen for a comparative stratigraphic and palaeoceanographic study. Magnetostratigraphy, nannofossil and planktonic foraminiferal zonations as well as a high-resolution oxygen-isotope stratigraphy were established (Beiersdorf et al., in press; Bickert et al., 1994). The palaeomagnetic polarity scale indicates that the record goes back to the Late Pliocene and that the core base is approximately 2.6 million years old (Fig. 2). A continuous oxygen isotope record reveals that no larger hiatus is present. Core $34 \mathrm{KL}$ therefore provides a suitable section to determine stratigraphic ranges of benthic foraminifers in a high pelagic environment and to describe long term variations in assemblage composition. Palaeoenvironmental implications, as inferred from flux rates and the foraminiferal community structure, are discussed.

\section{MATERIAL AND METHODS}

Ninety-one volume-defined samples, on average $20 \mathrm{~cm}^{3}$, were taken from core $34 \mathrm{KL}$ by using the syringe method. The samples were washed on a $63 \mu \mathrm{m}$ mesh, the residues were dried and split into two aliquots. From 59 selected samples, benthic foraminifers were picked from the $250-2000 \mu \mathrm{m}$ fraction of one half-split. This grain-size fraction was chosen because of the better observation of assemblage fluctuations owing to the smaller species number and because of the elimination of smaller forms which are more easily displaced by redeposition (Lohmann, 1978; Lutze \& Coulbourn, 1984). Foraminiferal tests were 


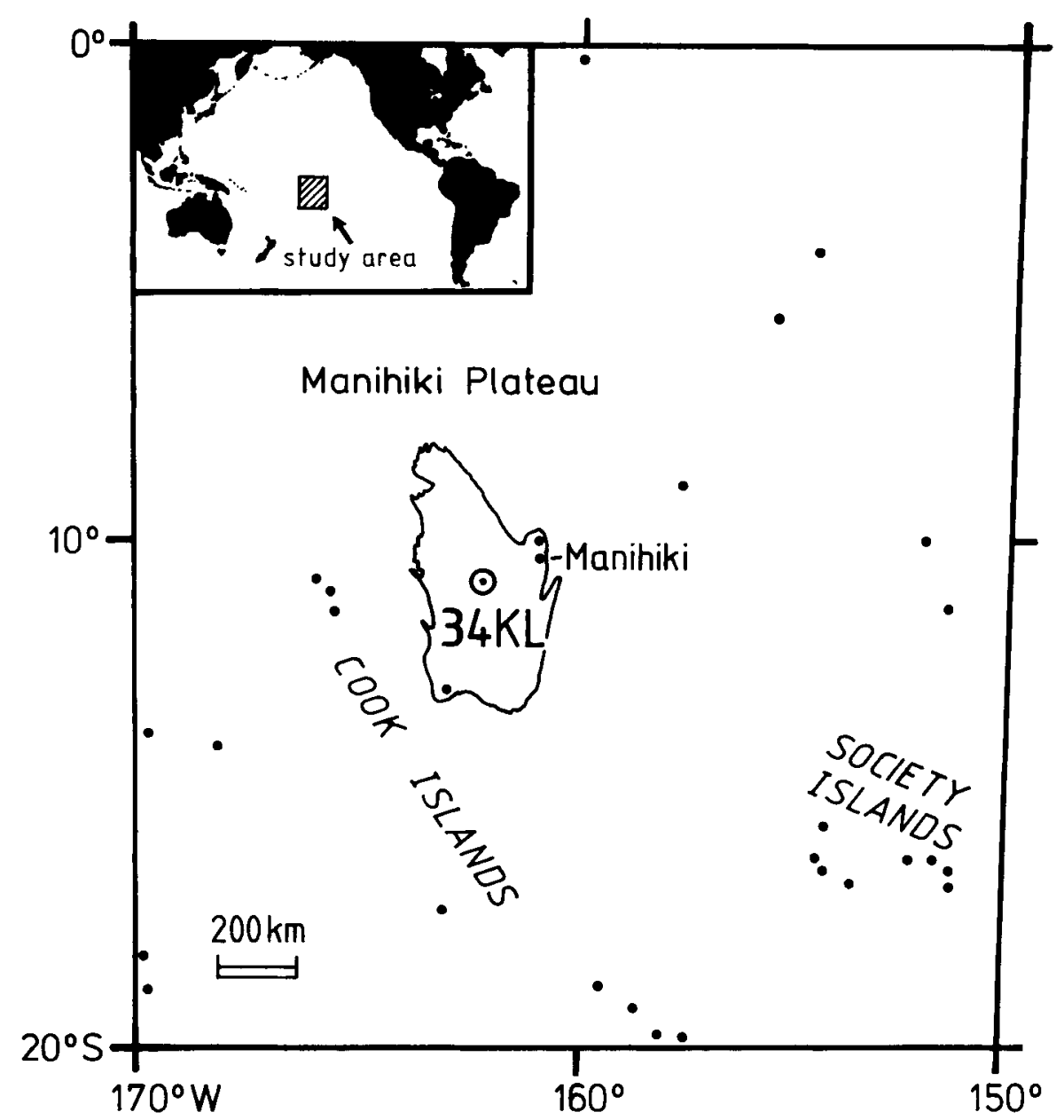

Fig. 1. Geographical setting of the Manihiki Plateau and core 34KL. The plateau is indicated by the $3500 \mathrm{~m}$ depth contour (Beiersdorf, 1990).

collected in Plummer cell-slides where they were sorted on species level, fixed, and counted. The total number of tests collected varied from 37 to 167 specimens. The content of benthic foraminifers per gram dry sediment is in the range of 4.1 to 18.8 tests for the $250-2000 \mu \mathrm{m}$ fraction.

The age model of Beiersdorf et al. (1993) which has been developed from the oxygen isotope stratigraphy, was used for the present study. This model is based on the SPECMAP time scale (Imbrie et al., 1984) and the astronomical calibrated timescale of Shackleton et al. (1990) which is also applied to the magnetostratigraphy at this core. Ages of biostratigraphic data were determined by linear interpolation between adjacent oxygen isotopic events.

Flux rates were calculated for selected foraminiferal species and assemblages from the census data by using the following equation (after Schönfeld, 1990):

$$
\mathrm{FR}=\frac{\mathrm{BF} * \mathrm{AR}}{\mathrm{SW}}
$$

where FR is the flux rate of benthic foraminifers [specimens $/ \mathrm{cm}^{2 *} \mathrm{ky}$ ], BF is the number of benthic foramini- fers in the whole sample, AR is the sediment accumulation rate $\left[\mathrm{g} / \mathrm{cm}^{2 *} \mathrm{ky}\right]$ and $\mathrm{SW}$ is the sample weight $[\mathrm{g}]$. The accumulation rates were taken from Beiersdorf, et al. (in press).

\section{BENTHIC FORAMINIFERAL ASSEMBLAGES FROM THE MANIHIKI PLATEAU}

Sixty-one different benthic foraminiferal species were identified (Tab. 1). The assemblage is dominated by calcareous-perforate species (49), the diversity of arenaceous (5) and miliolid (7) foraminifers is rather low.

Cibicidoides wuellerstorfi and Oridorsalis umbonatus are the dominant faunal elements with mean proportions of 30 and $12 \%$ respectively (Table 2). Melonis pompilioides, Pullenia bulloides, Anomalina globulosa, and Pyrgo murrhina are frequent species. Common but occasional dominant faunal elements are Cibicidoides robertsonianus, Eggerella bradyi, Gyroidina zelandica, Karreriella bradyi, Melonis barleeanum, Nonion sp. and Pyrgo serrata. This benthic foraminiferal assemblage displays bathyal charac- 


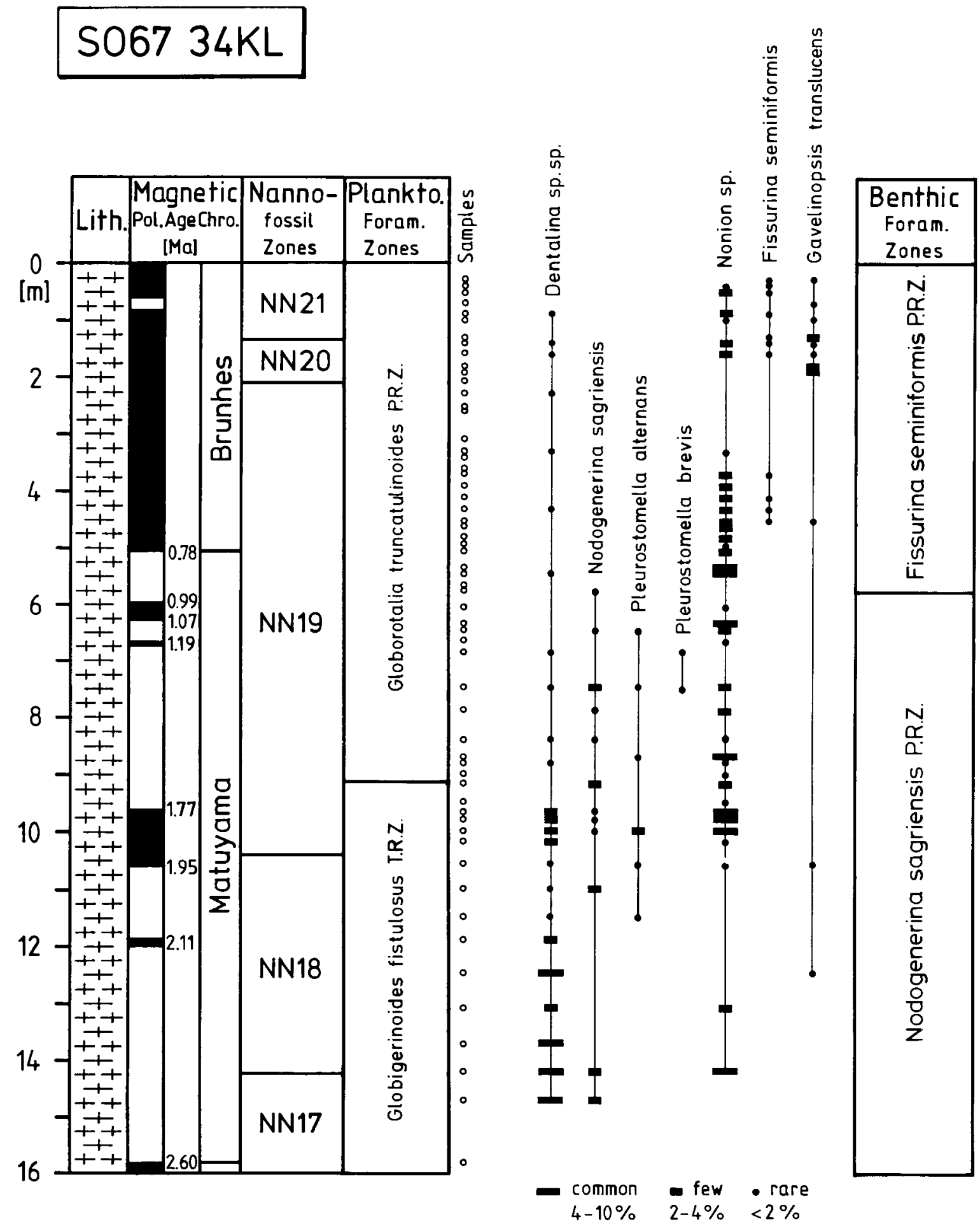

Fig. 2. Stratigraphic ranges of benthic foraminiferal index species and benthic foraminiferal zonation from core 34KL (Manihiki Plateau, southwestern tropical Pacific). Lithology (foram-nanno ooze throughout), magnetostratigraphy, nannofossil zonation, and planktonic foraminiferal zones are given for comparison (Beiersdorf et al., 1993). The Upper Pliocene/Pleistocene boundary is drawn with the base of nannofossil zone NN19. Absolute ages of magnetostratigraphic events after Shackleton et al. (1990).

teristics. It shows close affinities to the 'plate bathyal assemblage' of Resig (1981) and to foraminiferal assemblages from the Ontong Java Plateau (Burke et al., 1993). Epistominella umbonifera and other typical bathyal species from the Pacific are rare. Their scarcity may, however, result from the chozen grain- size fraction. Tests of Epistominella spp. usually have a smaller diameter and most of them are recorded in the $63-250 \mu \mathrm{m}$ fraction. 
Table 1. Benthic foraminiferal species. Note: Taxonomic references were given by Barker (1960) and Ellis \& Messina (1940-1978). They are not included in the reference list.

Ammobaculites reophaciformis Cushman, 1911

Ammosphaeroidina sphaeroidiniformis (Brady, 1884)

Anomalina globulosa Chapman \& Parr, 1937

Bulimina alazanensis (Cushman, 1927)

Cassidulina subglobosa Brady, 1881

Chilostomella ovoidea Reuss, 1850

Cibicidoides kullenbergi (Parker, 1953)

Cibicidoides pseudoungerianus (Cushman, 1922)

Cibicidoides robertsonianus (Brady, 1881)

Cibicidoides wuellerstorfi (Schwager, 1866)

Dentalina communis Orbigny, 1826

Dentalina comatula (Cushman, 1923)

Dentalina filiformis Orbigny, 1826

Dentalina intorta (Dervieux, 1894)

Eggerella bradyi (Cushman, 1911)

Epistominella exigua (Brady, 1884)

Epistominella umbonifera (Cushman, 1933)

Epistominella rugosa (Phleger \& Parker, 1951)

Favocassidulina favus (Brady, 1884)

Fissurina alveolata (Brady, 1884)

Fissurina cf. fimbriata (Brady, 1881)

Fissurina seminiformis (Schwager, 1866)

Fissurina trigono-marginata (Parker \& Jones, 1865)

Fissurina wiesneri Barker, 1960

Gavelinopsis translucens (Phleger \& Parker, 1951)

Glandulina laevigata Orbigny, 1826

Gyroidina cf. lamarckiana (Orbigny, 1839)

Gyroidina orbicularis Orbigny, 1826

Gyroidina zelandica Finlay, 1939

Karreriella bradyi (Cushman, 1911)

Lagena laevicostata Cushman \& Gray, 1946

Lagena striata (Orbigny, 1839)

Laticarinina pauperata (Parker \& Jones, 1865)

Lenticulina gibba (Orbigny, 1839)

Melonis barleeanum (Williamson, 1858)

Melonis pompilioides (Fichtel \& Moll, 1798)

Nodogenerina sagrinensis (Bagg, 1912)

Nodosaria radicula (Linné, 1758)

Nonion sp. Parker, 1964

Oolina globosa (Montagu, 1803)

Oolina cf. longispina (Brady, 1881)

Oridorsalis umbonatus (Reuss, 1851)

Orthomorphina challengeriana (Thalmann, 1937)

Osangularia cultur (Parker \& Jones, 1865)

Pleurostomella alternans Schwager, 1866

Pleurostomella brevis Schwager, 1866

Pullenia bulloides (Orbigny, 1826)

Pullenia quinqueloba (Reuss, 1851)

Pyrgo murrhina (Schwager, 1866)

Pyrgo serrata (Bailey, 1861)

Pyrulina angusta (Egger, 1857)

Pyrulina extensa (Cushman, 1923)

Pyrulina cf. fusiformis (Roemer, 1838)

Pyrulina cf. gutta Orbigny, 1826

Quinqueloculina cf. lamarckiana Orbigny, 1839

Quinqueloculina seminula -group Linné

Quinqueloculina venusta Karrer, 1868

Sigmoilinita distorta (Phleger \& Parker, 1951)

Textularia australis Parr, 1950

Triloculina tricarinata Orbigny, 1826

Uvigerina auberiana Orbigny, 1839

\section{BENTHIC FORAMINIFERAL BIOZONES}

A new benthic foraminiferal biozonation is proposed for the succession at core $34 \mathrm{KL}$. The zones may be further subdivided by stratigraphical restricted acme occurrences.
Stratigraphic ranges of index species and the biozonation are shown in Fig. 2.

\section{Nodogenerina sagriensis Partial Range Zone}

Lowermost section part, from core base to $566.5 \mathrm{~cm}$ $(>2,594-996 \mathrm{ka})$

Lower boundary: Not defined

Upper boundary: The last occurrence of Nodogenerina sagriensis

The upper boundary of this zone corresponds to the 'Stilostomella extinction' around the Brunhes/Matuyama boundary described from the Eastern Atlantic. It is located $61.5 \mathrm{~cm}$ below this magnetic reversal at core $34 \mathrm{KL}$. The age of the last occurrence of Nodogenerina sagriensis, as interpolated between oxygen isotopic events 25 and 29 , is distinctively older than those given by Weinholz \& Lutze (1989, fig.1) which were calculated by linear interpolation between magnetostratigraphic events. If the age model of Weinholz \& Lutze (1989, fig. 1) is applied to the 'Stilostomella extinction' at core 34KL (Brunhes/Matuyama boundary: $730 \mathrm{ka}$, top Jamarillo Event: $910 \mathrm{ka}$ ), the resulting age of $760 \mathrm{ka}$ is well within the range given by Weinholz \& Lutze (1989). As such, the last occurrence of Nodogenerina sagriensis at this site in the southwestern tropical Pacific documents a world-wide extinction event.

Nodogenerina sagriensis is the only 'Stilostomella' recorded at core $34 \mathrm{KL}$. This species survives Pleurostomella alternans and Pleurostomella brevis which disappear below, at 634 and $670.5 \mathrm{~cm}$ respectively. Their last occurrence data are, however, time transgressive. Pleurostomella brevis disappears in the Eastern Atlantic later (above top Jamarillo Event) than on the Manihiki Plateau (below Jamarillo Event). Pleurostomella alternans is still present in the Eastern Atlantic today: living specimens were found in surface samples off Cape Blanc and from the deep Guinea Basin (Timm, pers. comm.).

From $1070.5 \mathrm{~cm}(1,980 \mathrm{ka})$ on, Nonion sp. occurs with moderate abundances in most of the samples examined, which is only $29 \mathrm{~cm}$ below the base of the nannofossil zone NN19. No corresponding acme occurrence of Nonion sp. has been reported to date. This species has been described by Parker (1964) from the experimental Mohole drillsite near Guadalupe Island off Baja California, where it ranges from Middle Miocene to Pliocene.

Dentalina spp. occur with moderate abundances below $957 \mathrm{~cm}(1,725 \mathrm{ka})$, but they are rare above. This datum coincides roughly with the top of the Olduvai Event. Downhole increasing abundances of Nodosariacea towards the Pliocene/Pleistocene are documented from many DSDP Sites (e.g. Caralp, 1984; Keller, 1980) but are not constrained to date.

\section{Fissurina seminiformis Partial Range Zone}

From $566.5 \mathrm{~cm}$ to $13.5 \mathrm{~cm}$ (core top) (996 ka to present)

Lower boundary: The last occurrence of Nodogenerina sagriensis

Upper boundary: not defined

Fissurina seminiformis occurs above $456.0 \mathrm{~cm}(0.755 \mathrm{ma})$ in most of the samples with low abundances, not exceeding $2 \%$. The species is not recorded, however, in a section 
Benthic foraminifera, Manihiki Plateau

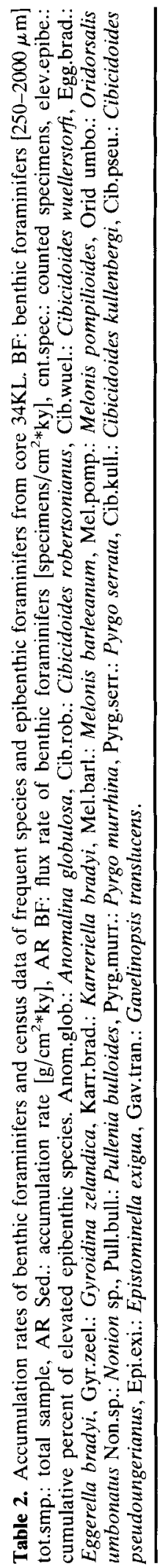

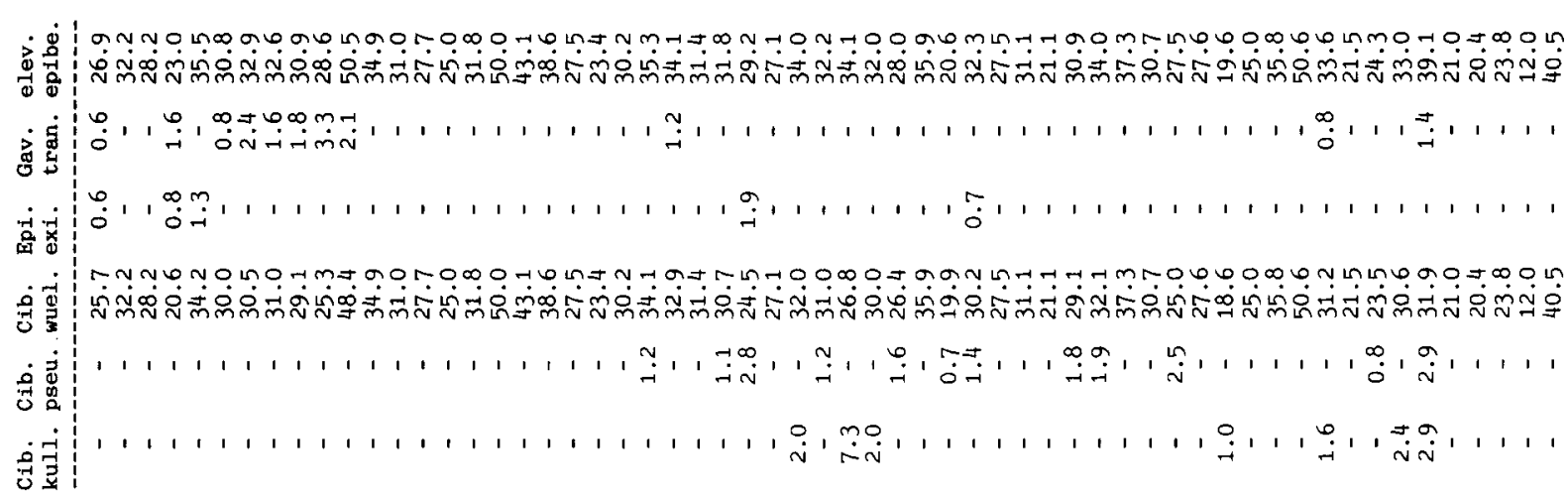

范造 安 它

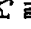
ت تं

安

官: m, or fr,

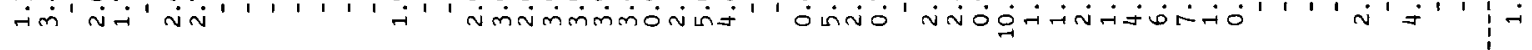

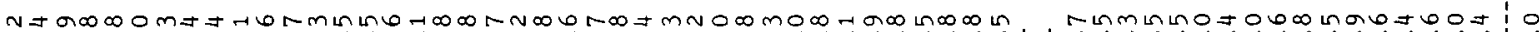

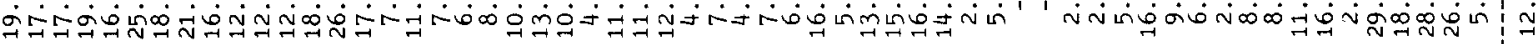
官 20 岀

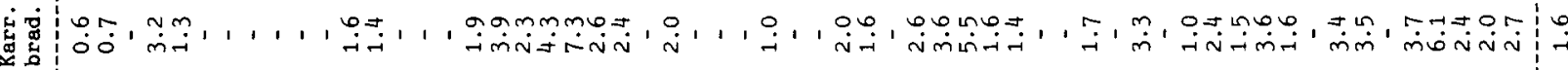

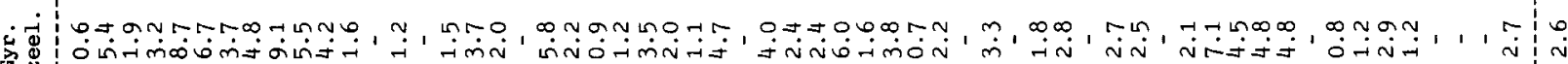

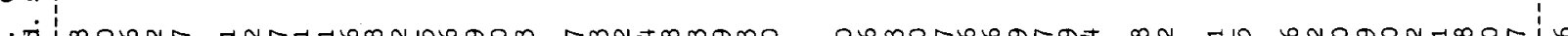

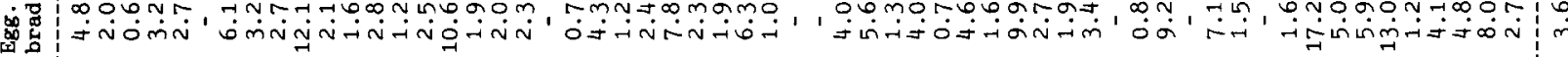

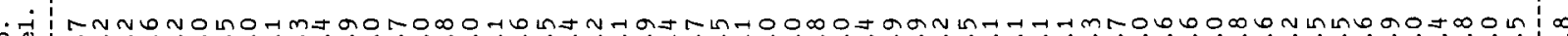

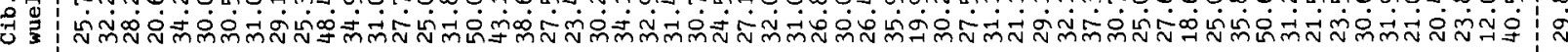

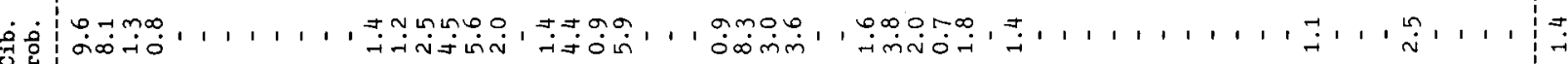

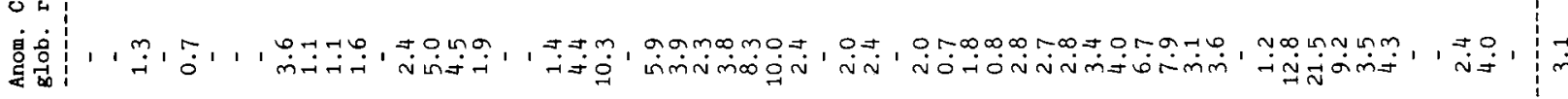

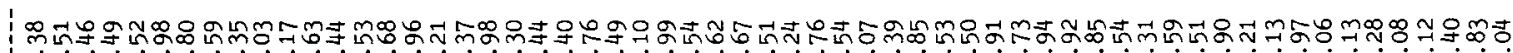
द

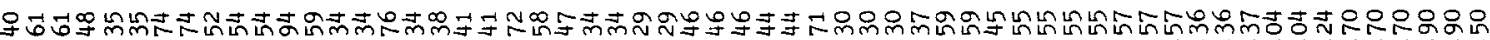
00000000000000000000000000000000000000000000000007-1000000

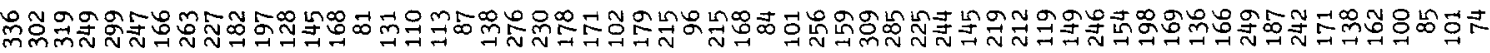
范 $\rightarrow$ | 9

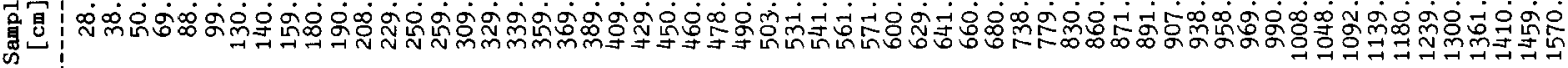




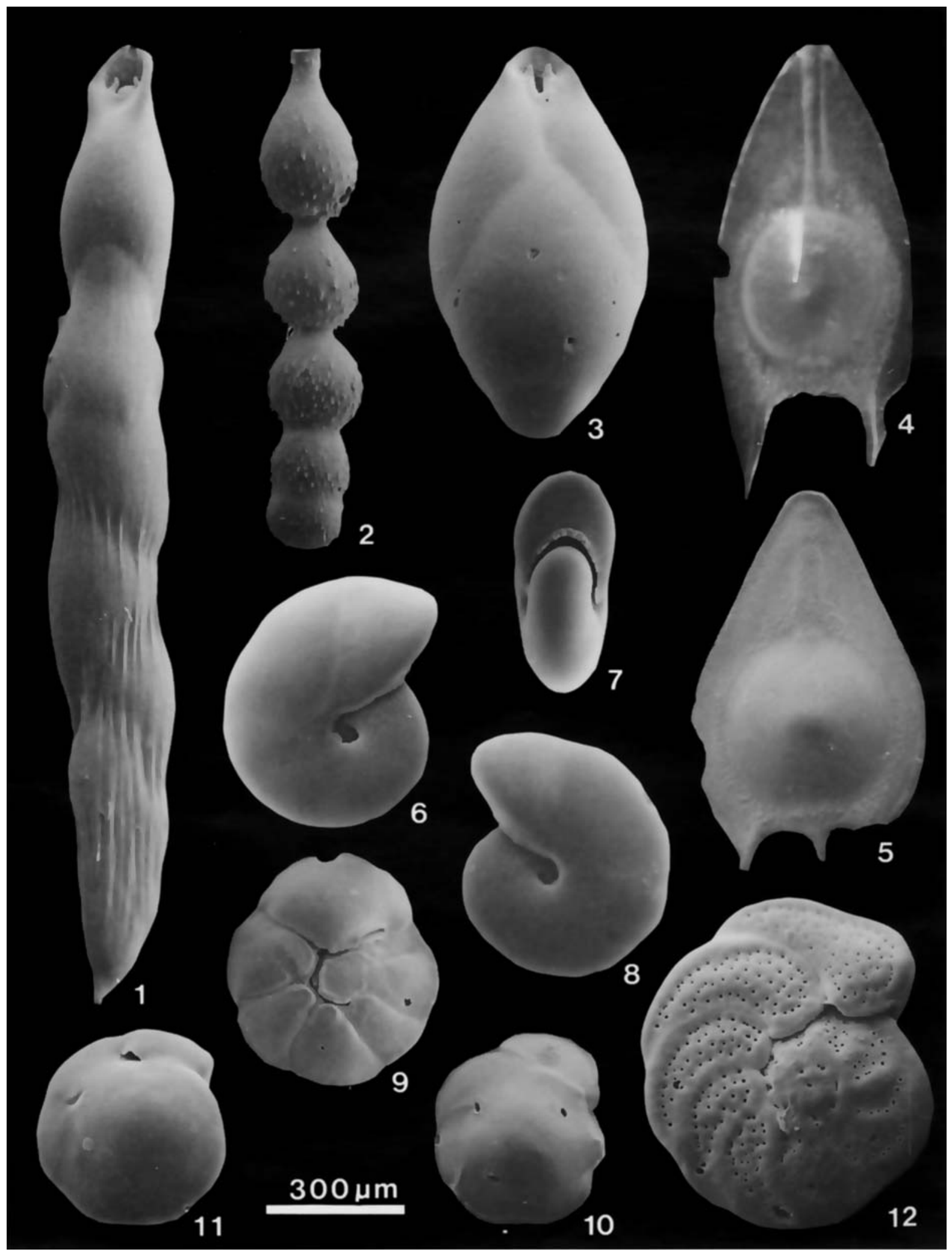

Plate 1 
interval between 364.5 and $170.0 \mathrm{~cm}$. A corresponding first-occurrence datum of Fissurina seminiformis has not been reported to date. Many authors do not take unilocular benthic foraminifers, e.g. Fissurina spp., into consideration because of their low abundances and high species diversification. Fissurina seminiformis is recorded, however, from Pazific DSDP Sites 173 (off California, Delaga Fan) and 208 (Lord Howe Rise) where it ranges from the lower Miocene to the Quaternary (Boltovskoy \& Guissani, 1990).

Above $199.5 \mathrm{~cm}$ (315 ka), Gavelinopsis translucens occurs in most of the samples examined with moderate abundances, not exceeding $3 \%$. No corresponding acme occurrence of Gavelinopsis translucens has been reported to date.

\section{FORAMINIFERAL COMMUNITY STRUCTURE AND PALAEOENVIRONMENTAL IMPLICATIONS}

The benthic foraminiferal assemblage composition allows only limited ecological conclusions. The tests of many living arenaceous species, which are commonly found in surface samples, are not preserved during fossilization or destroyed by sample processing (Schröder, 1986). A single, highly corroded specimen of ?Cribrostomoides ssp., which was found in the topmost sample, indicates that this generally observed pattern is also valid for core $34 \mathrm{KL}$. Benthic foraminiferal assemblages from the core samples may therefore not represent the ancient living communities (Lipps, 1983; Murray, 1984). The benthic foraminiferal assemblage composition was, however, certainly not biased by the effects of differential carbonate dissolution as the core site is located above the depth interval between 2.6 and $3.6 \mathrm{~km}$, where the lysocline fluctuated in the western equatorial Pacific during the Quaternary (Wu, et al., 1991).

\section{Palaeoenvironmental implications}

Cibicidoides wuellerstorf and Oridorsalis umbonatus are the most frequent species at this core. Paleoenvironmental implications are thus inferred from their ecology and habitat preferences.

Cibicidoides wuellerstorfi is a passive suspension feeder (Linke \& Lutze, 1993). It is found attached to various objects above the sediment/water interface and is assigned, together with Cibicidoides kullenbergi, Cibicidoides pseudoungerianus, Gavelinopsis translucens, and Epistominella exigua as 'elevated epibenthos'. The elevated position gives a better chance to catch food particles from slightly streaming water than on the sediment surface (Lutze \& Thiel, 1987; Linke, 1989). As such, high abundances of Cibicidoides wuellerstorfi indicate an environment which is characterized by near-bottom currents. The recent bottomcurrent activity is confirmed by ocean-bottom photographs, taken at the eastern flank of the Manihiki Plateau between 1400 and $2900 \mathrm{~m}$ waterdepth, which show oscillation ripples on the sediment surface (Beiersdorf, 1990). The net lateral transport may be, however, rather low as model calculations of water mass movements for the deep Pacific show at the Manihiki Plateau an East to West directed horizontal velocity vector of only $1 \mathrm{~cm} / \mathrm{s}$ at $2000 \mathrm{~m}$ waterdepth (Fujio \& Imasato, 1991, fig. 4b).

Oridorsalis umbonatus is detritivore and has an infaunal microhabitat preference (Murray, 1991). It populates the uppermost $2 \mathrm{~cm}$ of the sediment (tener in Corliss, 1985). Apparently tolerant to changing environmental conditions, Oridorsalis umbonatus occurs with high abundances in areas with low flux rates of particulate organic matter (Altenbach, pers. comm.; Haake \& Pflaumann, 1989).

The different habitat preferences and the use of different feeding strategies by Cibicidoides wuellerstorfi and Oridorsalis umbonatus are clearly reflected by their contrary fluctuating percentages (Fig. 3). The contrast is also expressed by a negative correlation coefficient of -0.39 $(n=59)$. The flux rates of both species show, however, congruent fluctuations and are highly positive correlated (r: $0.65, \mathrm{n}=59$ ). As the flux rate of benthic foraminifers is related to the food supply (Lutze, et al., 1986), it is concluded that the different feeding strategies of these species are linked to one source. The most likely source is lateral advection of particular organic matter by nearbottom currents because the suspension feeding Cibicidoides wuellerstorf $i$ dominates the foraminiferal assemblage.

During three short periods at oxygen isotope stages 9,13 and 65 , when the flux rate of benthic foraminifers was very low, Cibicidoides wuellerstorfi shows distinct frequency maxima exceeding $45 \%$ of the benthic foraminiferal fauna (Fig. 3). An explanation for this pattern which concurs with the above results is that the food supply was reduced drastically during these periods. The elevated epibenthic forms would then have a much better chance to collect food particles from the streaming water than those species settling on the sea-floor. Thus, the portion of elevated epibenthic forms in the total assemblage would increase.

\section{Flux rates of benthic foraminifers and organic matter: an assessment of lateral advection}

The absence or scarcity of productivity-sensitive Bolivina spp., Bulimina spp., Chilostomella spp. and Uvigerina spp. indicates that the flux of particulate organic matter to the sea-floor at the Manihiki Plateau is rather low (Lutze \&

Explanation of Plate 1

Index foraminifers and dominant species from core 34KL. Figures 1-3, 5-12 were made with a CamScan stereoscanning microscope (SEM), fig. 4 was taken with incident light by using a Wild M5A Photomicroscope. All specimens were left on SEM carriers which are stored in the collection of the Bundesanstalt für Geowissenschaften und Rohstoffe (Hanover). Collection numbers are given in brackets where the first number refers to the carrier and the second to the specimen on it. Fig. 1. Pleurostomella alternans Schwager, 1866 . Sample $641.5 \mathrm{~cm}$ (BGR596/13). Fig. 2. Nodogenerina sagrinensis (Bagg, 1912). Sample $641.5 \mathrm{~cm}$ (BGR596/14). Fig. 3. Pleurostomella brevis Schwager, 1866. Sample 680.5 cm (BGR598/5). Figs 4, 5. Fissurina seminiformis (Schwager, 1866): 4. Sample $130.5 \mathrm{~cm}, 5$. Sample $389.5 \mathrm{~cm}$ (BGR597/16). Figs 6-8. Nonion sp. Parker, 1964: 6. Sample $450.5 \mathrm{~cm}$ (BGR596/5), 7. Sample $450.5 \mathrm{~cm}$ (BGR596/6), 8. Sample 50.5 cm (BGR598/2). Figs 9, 10. Gavelinopsis translucens (Phleger \& Parker, 1951): 9. Sample 180.5 cm (BGR597/10), 10. Sample 130.5 cm (BGR596/1). Fig. 11. Oridorsalis umbonatus (Reuss, 1851). Sample $28.5 \mathrm{~cm}$ (BGR595/21). Fig. 12. Cibicidoides wuellerstorfi (Schwager, 1866). Sample 250.5 cm (BGR595/3). 


\section{Foraminiferal Composition}

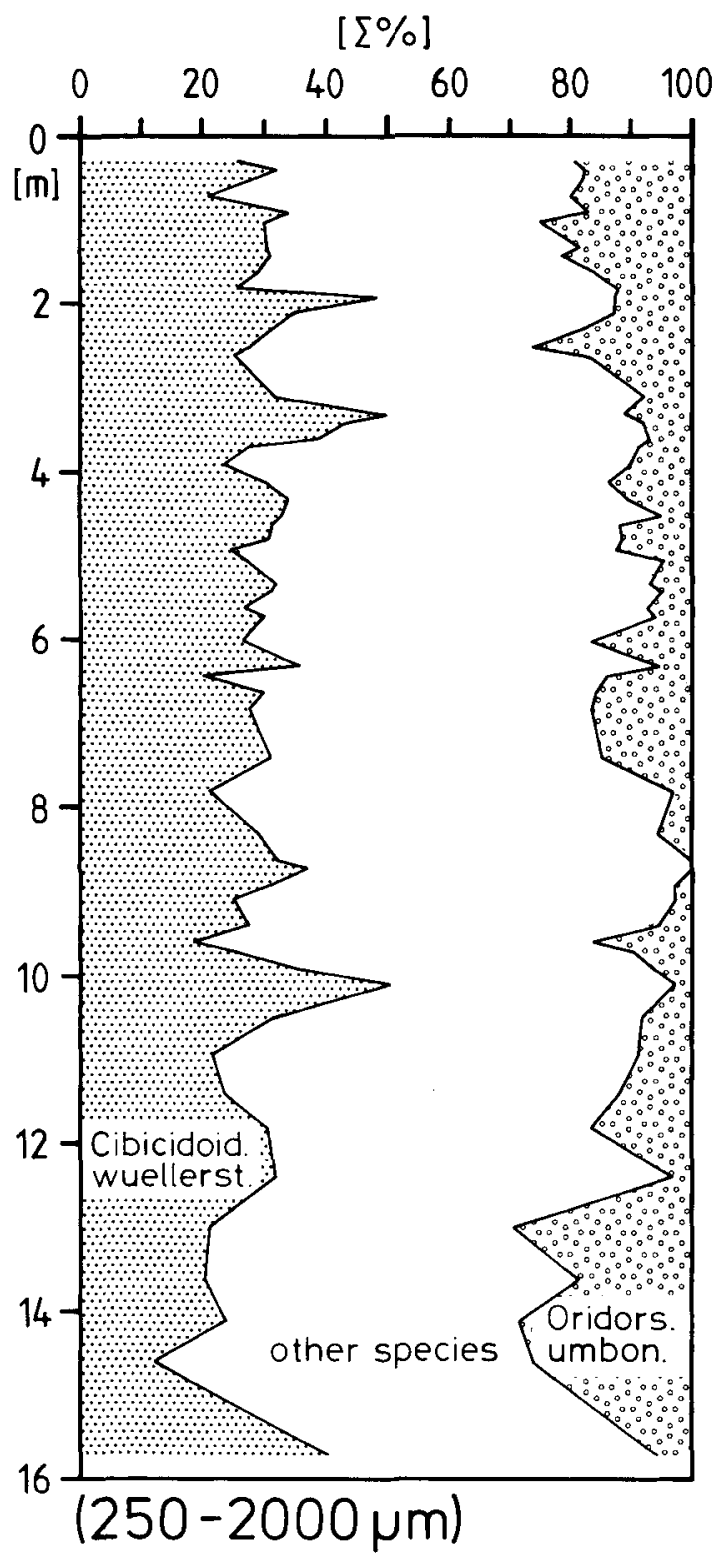

\section{Flux Rates}

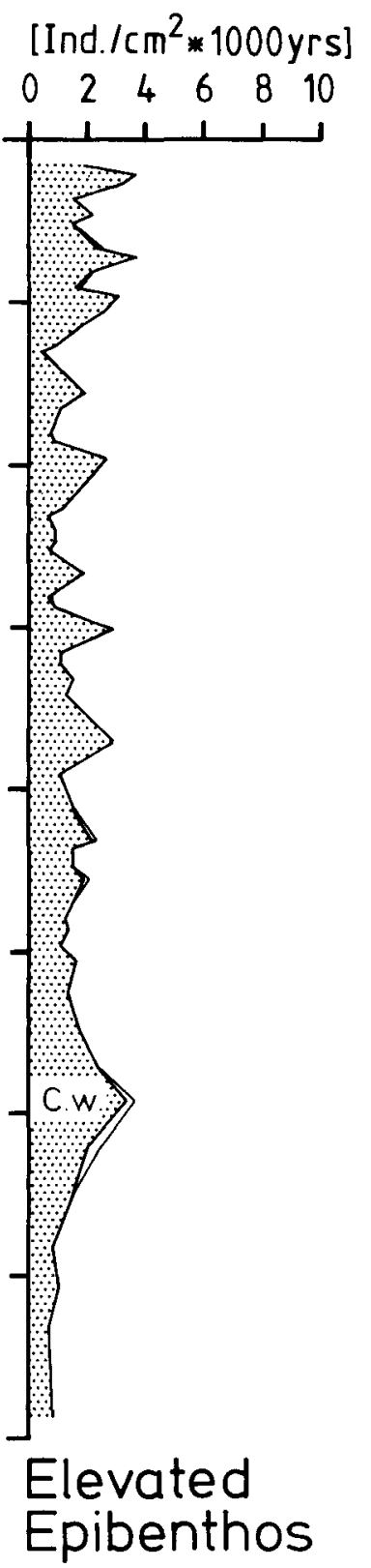

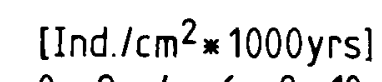

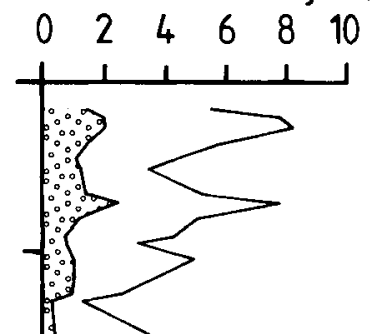

Fig. 3. Benthic foraminiferal composition of the grain-size fraction $250-2000 \mu \mathrm{m}$ and flux rates of elevated epibenthic and other benthic foraminiferal species. The faunal portions of Cibicidoides wuellerstorfi and Oridorsalis umbonatus are negatively correlated while their flux rates show congruent fluctuations. Maxima of Cibicidoides wuellerstorfi exceeding $40 \%$ are generally related to flux-rate minima. The elevated epibenthos comprises Cibicidoides kullenbergi, Cibicidoides pseudoungerianus, Cibicidoides wuellerstorfi, Epistominella exigua, and Gavelinopsis translucens.

Coulbourn, 1984; Altenbach \& Sarnthein, 1989; Loubere, 1991). A rough estimation of this flux can be made by using the abundance of Cibicidoides wuellerstorfi. As Cibicidoides wuellerstorfi was not recorded in any sample with a portion lower than $19 \%$, I assume that this species makes up approximately $20 \%$ of the recent dead assemblage in surface sediments at the coring site. Off North-West Africa, where this species occurs in water depths below $2000 \mathrm{~m}$ with portions of $10-30 \%$ of the dead assemblage (Lutze \&
Coulbourn, 1984; Lutze \& Thiel, 1987), flux rates of $1-3 \mathrm{~g} \mathrm{C}^{2 *} \mathrm{~m}^{2 *} \mathrm{a}$ are calculated by Altenbach (1985). Cibicidoides wuellerstorfi does not usually occur in areas where the flux of particulate organic matter is lower than $1.3 \mathrm{~g} \mathrm{C} / \mathrm{m}^{2 *} \mathrm{a}$ at the sea floor (Altenbach, pers. comm). If a surface-water productivity of $39 \mathrm{~g} \mathrm{C} / \mathrm{m}^{2 *} \mathrm{a}$ is assumed to prevail at the Manihiki Plateau (Berger et al., 1987) and the empirical flux-transfer function of Herguera \& Berger (1991) is applied, the remaining flux of organic matter at 
$2600 \mathrm{~m}$ waterdepth is estimated as $0.53 \mathrm{~g} \mathrm{C} / \mathrm{m}^{2 *} \mathrm{a}$ which is lower than the above values. Although these values are only rough estimates containing many uncertainties (Berger \& Wefer, 1990) it is concluded, however, that lateral advection approximately doubles the flux of organic matter near the sea-floor on the Manihiki-Plateau.

Graf (1989) demonstrated that lateral advection plays an important role in benthic food supply. Lateral advection amplifies the flux of organic matter to the sea-floor by a factor of 4 to 7 during plankton-bloom periods and 2 on an annual basis as revealed from studies in the Kiel Bight (Balzer et al., 1986). These results would support the above conclusion.

In the Quaternary, the productivity in the equatorial Pacific was higher by a factor of 1.2 to 2 during glacial times as estimated by Archer (1991) and Herguera (1992). The test production of benthic foraminifers depends on benthic turnover-rates which are largely triggered by the flux of organic matter (Altenbach, 1992; Gooday, 1988). The accumulation rate of benthic foraminiferal tests should therefore be significantly higher during glacial than interglacial periods as recognized by Burke et al. (1993) at the Ontong Java Plateau. Although a single maximum in benthic foraminiferal flux rates coincides with the glacial

\section{Flux Rates}

$$
\text { [Ind. } / \mathrm{cm}^{2} * 1000 \mathrm{yrs} \text { ] }
$$

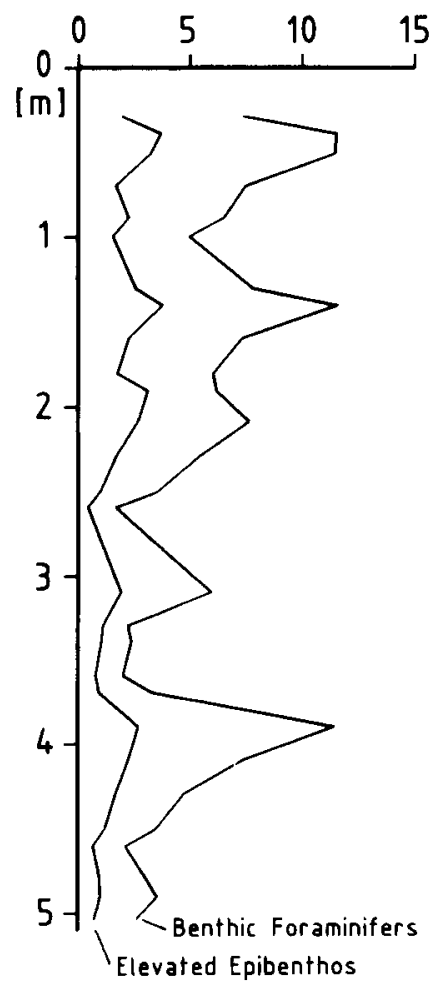

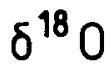

\section{[\%०]}

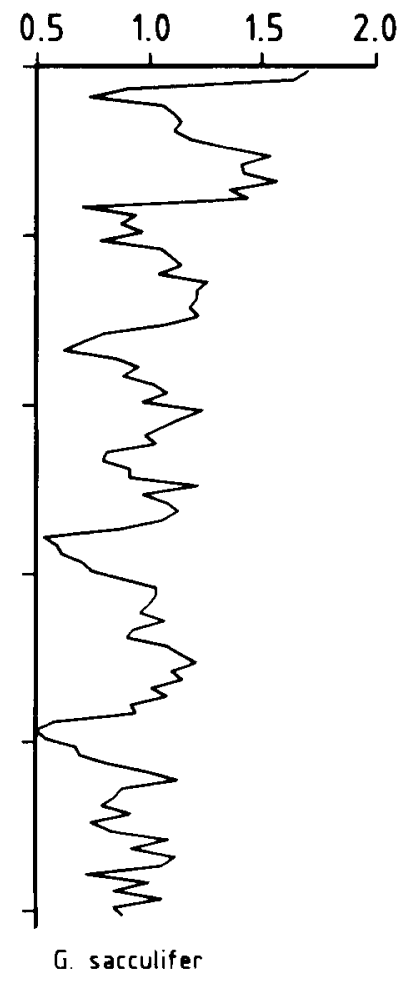

Fig. 4. Benthic foraminiferal flux rates and oxygen isotope record (Bickert, pers. comm.) of the Brunhes magnetochron. No correlation of foraminiferal flux rates and climate fluctuations is recognized. stage 16 at $393 \mathrm{~cm}$, no correlation of foraminiferal flux rates and climate fluctuations, as inferred from the oxygen isotope record, is recognized at core $34 \mathrm{KL}$ (Fig. 4). The incongruent pattern reveals that lateral advection near the sea-floor on the Manihiki Plateau and surface-water productivity may have fluctuated independently. They may even have balanced each other in a way that when productivity was higher the bottom-current activity may have been lower and thus may have reduced the lateral advection.

\section{SUMMARY}

Benthic foraminifera from the Manihiki Plateau (southwestern tropical Pacific) were studied at core 34KL. Sixty-one different species were identified. Cibicidoides wuellerstorfi and Oridorsalis umbonatus are dominant faunal elements while Melonis pompilioides, Pullenia bulloides, Anomalina globulosa, Pyrgo murrhina, Cibicidoides robertsonianus, Eggerella bradyi, Gyroidina zelandica, Karreriella bradyi, Melonis barleeanum, Nonion sp. and Pyrgo serrata are also frequent. This assemblage shows close affinities to the 'plate bathyal assemblage' of Resig (1981).

A new benthic foraminiferal biozonation is proposed for this core. The Nodogenerina sagriensis Partial Range Zone ranges from core base to $566.5 \mathrm{~cm}(>2,594-996 \mathrm{ka})$. The upper boundary is defined by the last occurence of the index species. This last occurence datum is time equivalent to the 'Stilostomella extinction' in the Eastern Atlantic (Weinholz \& Lutze, 1989) and thus documents this worldwide extinction event in the southwestern tropical Pacific. The Fissurina seminiformis Partial Range Zone comprises the upper part of the core from $566.5 \mathrm{~cm}$ to core top. The index species occurs above $456.0 \mathrm{~cm}$ in most of the samples. Fissurina seminiformis ranges, however, from the lower Miocene to the Quaternary at other sites in the Pacific.

The benthic foraminiferal assemblage allows only limited ecological conclusions. High abundances of Cibicidoides wuellerstorfi indicate an environment which is characterized by bottom-near currents. The absence or scarcity of highproductivity sensitive species indicates a considerably low flux of particulate organic matter to the sea floor on the Manihiki Plateau. This flux is constrained to be at present in the order of $0.53-3 \mathrm{~g} \mathrm{C} / \mathrm{m}^{2} * \mathrm{a}$. As the flux rate calculated from the surface-water productivity is significantly lower than that estimated from benthic foraminifers, it is concluded that lateral advection by bottom-near currents approximately doubles the flux of organic matter near the sea-floor on the Manihiki Plateau. Flux rates of benthic foraminifera show no correlation with the Quaternary oxygen-isotope record. This pattern indicates, that nearsurface productivity and lateral advection may have varied independently creating a mixed signal.

\section{ACKNOWLEDGEMENTS}

The study of benthic foraminifers is part of a joint multistratigraphical analysis of core $34 \mathrm{KL}$ which was initially proposed and co-ordinated by $\mathrm{H}$. Beiersdorf (Hanover). T. Bickert (Bremen), N. Petersen (Munich), P. Cepek and W. Weiss (Hanover) kindly provided data on oxygen isotopes, palaeomagnetism, nannofossils and planktonic foraminifers 
respectively. Their encouragement is gratefully acknowledged. A. Altenbach (Kiel) and A. Thies (Hanover) are thanked for thoughtful comments on foraminiferal ecology and the importance of lateral advection. Special thanks are offered to G.-F. Lutze, S. Timm (Kiel) and R. Schiebel (Tübingen) for their help with foraminiferal taxonomy. A. Bruns and H. Karman (Hanover) are thanked for technical assistance. The author was funded by the Bundesminister für Forschung und Technologie (Grant No. 03R399A1).

\section{Manuscript received May 1993 \\ Manuscript accepted June 1994}

\section{REFERENCES}

Altenbach, A.V. 1985. Die Biomasse der benthischen Foraminiferen. Auswertungen von 'Meteor'-Expeditionen im östlichen Nordatlantik. Unpublished Ph.D. thesis, Christian-AlbrechtsUniversität, Kiel.

Altenbach, A.V. 1992. Short term processes and patterns in the foraminiferal response to organic flux rates. Marine Micropaleontology, 19: 119-129.

Altenbach, A.V. \& Sarnthein, M. 1989. Productivity record in benthic foraminifera. In Berger, W., Smetacek, V. \& Wefer, G. (Eds), Productivity of the Ocean: Present and Past, 255-269, Wiley, New York.

Archer, D.E. 1991. Equatorial Pacific calcite preservation cycles: Production or dissolution? Paleoceanography, 6: 561-571.

Balzer, W., Pollehne, F. \& Erlcnkeuser, H. 1986. Cycling of organic carbon in a coastal marine system. In Sly, P.G. (Ed.), Sediments and water interactions, 323-328, Springer, New York.

Barker, R.W. 1960. Taxonomic Notes on the Species Figures by H. B. Brady in his Report on the Foraminifera Dredged by H.M.S. Challenger During Years 1873-1876. Society of Economic Palcontologists and Mineralogists, Special Publication, 9.

Beiersdorf, H. 1990. Geoscientific investigations at the Manihiki Plateau (Southwest Pacific Ocean). Unpublished Report, Bundesanstalt für Geowissenschaften und Rohstoffe, Hanover.

Beiersdorf, H., Bickert, T., Cepek, P., Fenner, J., Petersen, N., Schönfeld, J., Weiss, W. \& Won, M.-Z. in press. High-resolution stratigraphy and the response of biota to late Cenozoic environmental changes in the central equatorial Pacific Ocean (Manihiki Plateau). Marine Geology.

Berggren, W.A. \& Miller, K.G. 1989. Cenozoic bathyal and abyssal calcareous benthic foraminiferal zonation. Micropaleontology, 35: 308-320.

Berger, W., Fischer, K., Lai, C. \& Wu, G. 1987. Ocean productivity and organic carbon flux. Part I. Overview and maps of primary production. SIO Reference Series, 87-30: 67 pp., Scripps Institution of Oceanography, San Diego.

Berger, W.H. \& Wefer, G. 1990. Export production: seasonality and intermittency, and paleoceanographic implications. Palaeogeography, Palaeoclimatology, Palaeoecology (Global Planetary Change Section), 89: 245-254.

Bickert, T., Beiersdorf, H. \& Wefer, G. 1994. High vs. low productivity areas in the western Pacific: a comparison of Ontong Java and Manihiki Plateaus stable isotope records for the last $2.6 \mathrm{Ma}$. Unpublished manuscript, University of Bremen.

Boltovskoy, E. \& Guissani, G. de Kahn 1990. Benthic unilocular calcareous foraminifers in Late Cenozoic deep-sea deposits of the Pacific and Atlantic oceans. Revista Española de Micropaleontologia, 22: 361-406.

Burke, S.K., Berger, W.H., Coulbourn, W.T. \& Vincent, E. 1993. Benthic Foraminifera in box core ERDC 112, Ontong Java Plateau. Journal of Foraminiferal Research, 23: 19-39.

Caralp, M.H. 1984. Quarternary calcareous benthic foraminifers, Leg 80. Initial Reports of the Deep Sea Drilling Project, 80: $725-755$.

Corliss, B.H. 1985. Microhabitats of benthic foraminifera within deep-sea sediments. Nature, 314: 435-438.
Ellis, B.E. \& Messina, A.R. 1940-1978. Catalogue of Foraminifera. American Museum of Natural History, New York.

Fujio, S. \& Imasato, N. 1991. Diagnostic calculation for Circulation and Water Mass Movement in the Deep Pacific. Journal of Geophysical Research, 96(C1): 759-774.

Gooday, A.J. 1988. A response by benthic foraminifera to the deposition of phytodetritus in the deep-sea. Nature, 332: 70-73.

Graf, G. 1989. Die Reaktionen des Benthals auf den saisonalen Partikelflu und die laterale Advektion, sowie deren Bedeutung für Sauerstoff- und Kohlenstoffbilanzen. Unpublished Habilitations Schrift, Sonderforschungsbereich 313, Christian-AlbrechtsUniversität, Kiel.

Gupta, A.K. 1993. Biostratigraphic vs. paleoceanographic importance of Stilostomella lepidula (Schwager) in the Indian Ocean. Micropaleontology, 39: 47-51.

Haake, F.-W. \& Pflaumann, U. 1989. Late Pleistocene foraminifera stratigraphy on the Voring Plateau, Norwegian Sea. Boreas, 18: $343-356$.

Herguera, J.C. 1992. Deep-sea benthic foraminifera and biogenic opal: Glacial to postglacial productivity changes in the western equatorial Pacific. Marine Micropaleontology, 19: 79-98.

Herguera, J.C. \& Berger, W.H. 1991. Paleoproductivity from benthic foraminifera abundance: Glacial to postglacial change in the west-equatorial Pacific. Geology, 19: 1173-1176.

Imbrie, J., Shackleton, N.J., Pisias, N.G., Morley, W.L., Prell, W.L., Martinson, D.G., Hays, J.P., McIntyre, A. \& Mix, A.C. 1984. The orbital theory of Pleistocene climate: Support from a revised chronology of the marine $\delta^{18} \mathrm{O}$ record. In Berger, A., Imbrie, J., Mays, J., Kukla, G. \& Saltzman, B. (Eds), Milankovitch and Climate, 269-305, D.Reidel, Dordrecht.

Keller, G. 1980. Benthic foraminifers and paleobathymetry of the Japan Trench area, Leg 57, Deep Sea Drilling Project. Initial Reports of the Deep Sea Drilling Project, 56-57(2): 835-865.

Linke, P. 1989. Lebendbeobachtungen und Untersuchungen des Energiestoffwechsels benthischer Foraminiferen aus dem Europäischen Nordmeer. Berichte aus dem Sonderforschungsbereich 313 an der Christian-Albrechts-Universität zu Kiel, 18: $1-123$.

Linke, P. \& Lutze, G.F. 1993. Microhabitat preferences of benthic foraminifera - a static concept or a dynamic adaptation to optimize food acquisition? Marine Micropaleontology, 20: 215-234.

Lipps, J.H. 1983. Biotic interactions in benthic Foraminifera. In Tevesz, M.J.S. \& McCall, P.L. (Eds), Biotic Interactions in Recent and Fossil Benthic Communities, 331-376. Plenum, London.

Lohmann, G.P. 1978. Abyssal benthonic foraminifera as hydrologic indicators in the Western South Atlantic Ocean. Journal of Foraminiferal Research, 8: 6-34.

Loubere, P. 1991. Deep-Sea benthic foraminiferal response to a surface ocean productivity gradient: a test. Paleoceanography, 6: 193-204.

Lutze, G.-F. 1979. Benthic Foraminifers at Site 397: Faunal fluctuations and Ranges in the Quarternary. Initial Reports of the Deep Sea Drilling Project, 47: 419-431.

Lutze, G.-F. \& Coulbourn, W.T. 1984. Recent benthic Foraminifera from the continental margin of northwest Africa: community structures and distribution. Marine Micropaleontology, 8: 361-401.

Lutze, G.-F., Pflaumann, U. \& Weinholz, P. 1986. Jungquartäre Fluktuationen der benthischen Foraminiferenfaunen in TiefseeSedimenten vor NW-Afrika-Eine Reaktion auf Produktivitätsänderungen im Oberflächenwasser. 'Meteor'Forschungs Ergebnisse, C40: 163-180.

Lutze, G.F. \& Thiel, H. 1987. Cibicidoides wuellerstorfi and Planulina ariminensis, elevated epibenthic Foraminifera. Berichte aus dem Sonderforschungsbereich 313 an der Christian-AlbrechtsUniversität zu Kiel, 6: 17-30.

Murray, J.W. 1984. Benthic Foraminifera: Some relationships between ecological observations and palaeoecological interpretations. In Ocrtli, H. (Ed.), Benthos '83: 2nd International Symposium on Benthic Foraminifera (Pau, April 1983), 465-469. Elf-Aquitaine, Esso REP and Total CEP, Bordeaux. 
Murray, J.W. 1991. Ecology and paleoecology of benthic foraminifera. $397 \mathrm{pp}$., Longman, London.

Parker, F.L. 1964. Foraminifera from the experimental Mohole Drilling near Guadalupe Island, Mexico. Journal of Paleontology, 38: $617-636$.

Resig, J. 1976. Benthic foraminiferal stratigraphy, eastern margin, Nazca Plate. Initial Reports of the Deep Sea Drilling Project, 34: 743-759.

Resig, J.M. 1981. Biogeography of benthic foraminifera of the northern Nazca plate and adjacent continental margin. Geological Society of America, Memoir, 154: 619-665.

Schönfeld J. 1990. Zur Stratigraphie und Ökologie benthischer Foraminiferen im Schreibkreide-Richtprofil von Lägerdorf/Holstein. Geologisches Jahrbuch, A117: 3-151.

Schönfeld, J. \& Spiegler, D. in press. Benthic foraminiferal biostratigraphy of ODP Site 141-861 (Chile Triple Junction,
Southeastern Pacific). Proceedings of the Ocean Drilling Program, Scientific Results, 141.

Schröder, C. 1986. Deep-water arenaceous foraminifera in the northwest Atlantic Ocean. Canadian technical report of Hydrography and Ocean Science, 71: 1-191.

Shackleton, N.J., Berger, A. \& Peltier, W.R. 1990. An alternative astronomical calibration of the lower Pleistocene timescale based on ODP Site 677. Transactions of the Royal Society of Edinburgh: Earth Sciences, 81: 251-261.

Weinholz, P. \& Lutze, G.-F. 1989. The Stilosiomella Extinction. Proceedings of the Ocean Drilling Program, Scientific Results, 108: $113-117$

Wu, G.P. Yasuda, M.K. \& Berger, W.H. 1991. Late Pleistocene carbonate stratigraphy on the Ontong-Java Plateau in the western equatorial Pacific. Marine Geology, 99: 135-150. 